\title{
Aykırı Değerlerin Tespiti ve Taşkın Debilerinin Hesabı için Bir Yöntem Geliştirilmesi
}

\author{
Mahsum AYDIN ${ }^{1}$ \\ Ahmet TUNA ${ }^{2}$
}

ÖZ

Bu çalışmada aykırı değerlerin belirlenmesi ve taşkın debilerinin hesabı için geliştirilen yeni bir metot önerilmektedir. Çalışmada Fırat havzası üzerinde bulunan 6 adet gözlem istasyonuna ait veriler kullanılmıştır. Bu gözlem istasyonlarına ait veriler analiz edilmiş ve aykırı değerler Rosner testi, Dixon Thompson testi ve önerilen yöntem ile tespit edilmiştir. Belirli tekerrür aralığında meydana gelebilecek olan taşkın debileri önerilen yöntem kullanılarak hesap edilmiştir. Aykırı değerler veri setlerinden çıkarılarak uyumun iyiliği testleri sonucu belirlenen olasılık yoğunluk fonksiyonları (OYF) kullanılarak taşkın debileri hesap edilmiştir. Ayrıca L momentler yöntemi ile parametreleri belirlenen en uygun OYF yardımıyla taşkın debileri bölgesel olarak hesap edilmiştir. Önerilen yöntem, taşkın frekans analizi ve L momentler yöntemi ile hesaplanan taşkın debisi değerleri karşılaştırıldığında önerilen yöntem ve noktasal taşkın frekans analizi ile belirlenen değerlerin L momentler yöntemi ile belirlenen değerlerden daha uygun ve kullanılabilir olduğu kanaatine varılmıştır.

Anahtar Kelimeler: Aykırı değer, taşkın frekans analizi, olasılık yoğunluk fonksiyonu, uyumun iyiliği testi, L momentler yöntemi, Fırat Havzası.

\section{ABSTRACT \\ Development of a New Method for Detecting Outliers and Calculating Flood Discharge}

In this study a new method has been proposed which was developed for detecting outliers and calculating flood discharge. In the study the data of six gauging stations on Euphrates basin have been used. The data of these stations were analyzed and the outliers were detected by using Rosner test, Dixon Thompson test and the proposed method. The flood discharge which can occur in a certain recurrence interval has been calculated by using the proposed method. After the outliers were removed from the datasets, the flood discharges were calculated by using probability density functions (PDF) which were determined by using goodness of fit tests. In addition, flood discharges are calculated regionally by using PDF

\footnotetext{
Not: Bu yaz1

- Yayın Kurulu'na 10.02.2016 günü ulaşmıştır. 25.07.2017 günü yayımlanmak üzere kabul edilmiştir.

- 31 Temmuz 2018 gününe kadar tartışmaya açıktır.

- DOI: $10.18400 /$ tekderg.373781
}

1 Yüzüncü Yıl Üniversitesi, İnşaat Mühendisliği Bölümü, Van - maydin@yyu.edu.tr

2 Firat Üniversitesi, İnşaat Mühendisliği Bölümü, Elazığ - atuna@firat.edu.tr 
whose parameters were determined by the L moments method. When the flood discharge values were calculated by using the proposed method, and when the flood frequency analysis and L moments methods were compared, it has been concluded that the values determined by the proposed method and flood frequency analysis are more suitable and usable than the values determined by the $\mathrm{L}$ moments method.

Keywords: Outliers, flood frequency analysis, probability density function, goodness of fit test, L moments method, Euphrates Basin.

\section{GİRiş}

Su yapılarının hesap ve tasarımı yapılırken gelebilecek en büyük taşkın debisi göz önüne alınarak hesap ve tasarımlar yapılmak suretiyle güvenli bir tasarım sağlanması amaçlanmaktadır. Ancak bu taşkın debileri hesaplanırken kullanılan veriler içerisinde aykırı değerlerin varlığı hesaplamaların yanlış yapılmasına ve su yapılarının boyutlandırılmasında büyük ebatlarda boyutlandırılmasına yol açarak yüksek maliyetlere neden olmasının yanı sıra daha küçük ebatlarda boyutlandırılmasına neden olup büyük felaketlere yol açabilir. Bu nedenle taşkın debilerinin hesabında kullanılan veriler içerisindeki bu aykırı gözlem değerlerinin tespit edilmesi ve bu gözlemlerin veri seti üzerindeki etkisinin azaltılması hesap sonuçlarımızın daha doğru ve anlamlı olmasını sağlayacaktır. Aykırı değerlerin teşhisi için birçok yöntem geliştirilmiştir, bu yöntemlerin birçoğu aykırı değerleri hesaplarken standart sapma, çarpıklık katsayısı, ortalama değer gibi veri setlerine bağlı istatistiki değerler kullanmaktadır. Ancak veri seti içerisinde mevcut olan aykırı değerleri tespit ederken bu veri setlerine ait istatistiki değerlerin kullanılması aykırı değerlerin teşhisinde hata yapılmasına ve veri seti içerisindeki aykırı değerlerin yeterli doğrulukta tespit edilememesine neden olacaktır. Bu çalışmada önerilen yeni yöntem sayesinde veri setleri içerisindeki aykırı değerleri tespit ederken standart sapma, çarpıklık katsayısı, ortalama gibi istatistiki değerler kullanılmamaktadır. Dolayısıyla hesaplamalar sonucu aykırı değerler daha doğru bir şekilde tespit edilebilmektedir.

\section{AYKIRI DEĞER}

Aykırı değerler, verinin geriye kalan kısmıyla tutarsız olan gözlemler şeklinde tanımlanabilir. Bir aykırı değer, verinin kalanından belirgin bir şekilde uzak ya da farklı olan ya da verilerin çoğunluğu ile oldukça tutarsız olan bir gözlemdir. Eğer istatistikî bir modelin gerçek veri üreten mekanizmaya yakın olduğunu varsayarsak, aykırı değerleri gerçek modelden sapan değerler olarak ele alabiliriz. Böylece birçok durumda aykırı değerler, kendi gerçek değerlerinden sapan gözlemler olarak yorumlanabilir ya da eksik gözlenen değerler veya yanlış ölçülen değerler olarak da yorumlanabilirler [1].

Aykırı gözlemler, verinin çoğunluğundan belirgin bir şekilde sapan değerlerdir. Verinin çoğunluğunun uyduğu mekanizmadan farklı bir şekilde oluşmuş olabilirler veya kayıt hatası, üretim aşamasında bir bozukluk veya insanlarla ilişkili sebeplerden meydana gelebilirler. Aykırı gözlemler model kurma hatasına, yanlış parametre tahminlerine veya yanlış analiz sonuçlarına sebep olabilirler [2]. Bu nedenle aykırı değerlerin veri içerisinde tespit edilmesi ve etkilerinin giderilmesi doğru hesap yapma ve model kurma açısından oldukça önemlidir. 
Hidrolojik verilerde aykırı değerlerin tespit edilebilmesi için birçok yöntem geliştirilmiştir bu yöntemlerden bazıları; Chauvent, Dixon Thompson, Rosner metotlarıdır.

\subsection{Chauvenet Yöntemi}

Chauvenet yöntemi, örnekteki tek bir değerin örneğin geriye kalan noktalarından farklı bir popülâsyondan gelip gelmediğini belirlemek için kullanılır. Kritik değerler normal dağılım varsayımına dayanır. Test edilecek veri noktası, ortalamadan en çok sapan örnek değeridir $\left(\mathrm{X}_{0}\right)$. Nokta, ortalamanın altında ya da üstünde yer alabilir. Bu testin hipotezi şu şekildedir:

$\mathrm{H}_{0}$ : Örnekteki tüm noktalar aynı normal popülâsyondan gelmektedir.

$\mathrm{H}_{1}$ : Örnekteki en uç örnek noktasının, kalan örnek noktaları çizildiğindeki normal popülâsyondan gelmesi mümkün değildir.

Sıfır hipotezinin reddedilmesi, test edilen en uç örnek değerinin bir aykırı değer olduğunu gösterir. Değerin bir aykırı değer olarak belirlenmesinin nedeni aynı zamanda, veri son derece çarpık bir dağılımdan geldiğinde, testin normallik varsayması olabilir.

Chauvenet metodunda test istatistiğinin hesaplanabilmesi için, ilgili popülâsyon parametreleri $\mu$ 'nun tahmini $\bar{X}$ (örnek ortalaması) ve $\sigma$ 'nın tahmini S (standart sapma) değerlerine ihtiyaç vardır. Böylece örnekteki en uç değer, $\mathrm{X}_{0}$, belirlenir ve standart normal sapma uç değer Z'nin hesaplanmasında kullanılabilir:

$$
Z=\frac{X_{0}-\bar{X}}{S}
$$

Eğer yukarıdaki denkleme göre hesaplanan $Z$ değeri $Z_{p / 2}$ değerini aşıyorsa sıfır hipotezi reddedilir. $Z_{\mathrm{p} / 2}$ değerleri $\mathrm{p} / 2$ olasılığ 1 girilerek standart normal tablodan doğrudan doğruya görülebilir. $\mathrm{p}=1 /(2 \mathrm{n})$ şeklindeki Chauvenet kriteri uygulandığında bu iki kuyruklu bir testtir ve tek kuyruklu bir test olarak uygulanamaz. Bu, yalnızca tek bir aykırı değerin testinde kullanılabilir ve eğer en uç değer bir aykırı değer olarak kabul edildiyse ikinci bir gözleme uygulanamaz [3].

\subsection{Dixon-Thompson Testi}

Aykırı değerler için Dixon-Thompson (1953) testi de, belirli bir noktanın, veri setinin kalanıyla aynı popülâsyondan gelip gelmediğinin belirlenmesinde kullanılabilir. Bu özel test, küçük örnek boyutlarına sahip (en fazla 25 gözlem içeren) veri setlerinde kullanılabilmektedir. Bu testin varsayımları:

1. Veri, normal bir dağılımdan bağımsız ölçümler içerir.

2. Aykırı değer olarak tespit edilen aşırı uç olaylar, ya kayan bir ortalaması olan ya da aynı ortalaması olan fakat daha büyük bir varyansa sahip bir popülâsyondan gelebilirler. 
Dixon-Thompson testi, yalnızca tek bir aykırı değerin tespiti için geçerlidir. Bu testin kullanılabilmesi için, veri seti en büyükten en küçüğe doğru sıralanır ve en uç değer aykırı değer olarak test edilir. $\mathrm{Bu}$ nokta, örnek büyüklügüne bağlı test istatistiklerinden biri kullanılarak test edilir En uç değer $\mathrm{X}_{\mathrm{n}}$ olarak ifade edilirse Dixon Thompson test istatistiği aşağıdaki formüle göre hesaplanır:

$$
R=\frac{X_{n}-X_{n-2}}{X_{n}-X_{3}}
$$

Elde edilen $\mathrm{R}$ test istatistiği, \%5 anlamlılık düzeyi için hesaplanan kritik değerle karşılaştırılır. Eğer R değeri bu kritik değerden büyükse, bu nokta, aykırı değer olarak kabul edilecek bir aday olarak kabul edilir. Eğer nokta, bir aykırı değer olarak kabul edilirse, veri setinden ve diğer tüm alt hesaplamalardan çıkartılır [4].

\subsection{Rosner Testi}

Rosner (1983) testi tek bir aykırı değerin testi için öncelikle Grubbs (1969) tarafından önerilen ve daha sonra Grubbs ve Beck (1972) tarafindan tablolaştırılan aşırı studentlaştırılmış sapmanın (ESD) bir genellemesidir. Rosner'in genellemesi birden fazla aykırı değer içindir. Rosner testinin kullanılması için, mevcut potansiyel aykırı değerlerin sayısı üzerine bir üst limit (m) belirtilmelidir. Test, 25 ya da daha fazla sayıda gözlem içeren örnekler için geçerlidir.

m adet en uç gözlem çıkarıldıktan sonra kalan ölçümlerin $(n-m)$ ortalaması $\bar{x}_{m}$ ve standart sapmasi $s_{m}$ iken;

$$
\begin{aligned}
\bar{x}_{m} & =\frac{1}{n-m} \sum_{j=1}^{n-m} x_{j} \\
s_{m} & =\left[\frac{1}{n-m} \sum_{j=1}^{n-m}\left(x_{j}-\bar{x}_{m}\right)^{2}\right]^{1 / 2}
\end{aligned}
$$

m adet daha uç değer (büyük ya da küçük) tespit edildikten sonra ortalamadan $\left(\bar{x}_{m}\right)$ en uzak kalan gözlem $x_{m}$ olsun. Bu durumda:

$$
R_{m}=\frac{\left|x_{m}-\bar{x}_{m}\right|}{s_{m}}
$$

veri setinin tamamındaki $m$ adet en uç gözlem değerinin normal bir dağılımdan gelen aykırı değerler olup olmadıklarına karar vermek için kullanılan bir test istatistiğidir [5]. 


\section{4. Önerilen Yöntem}

Önerilen yöntemin diğer yöntemlere göre en büyük avantajı ortalama, standart sapma, çarpıklık vb. gibi istatistiki değerlerin kullanılmadan aykırı değerlerin tespit edilebilmesidir. Bunun en önemli nedeni ise bu istatistiki değerleri aykırı değerleri içinde barındıran veri setlerinden elde etmek zorunda oluşumuz ve aykırı değerlerin bu değerlerin çok yüksek ya da düşük çıkmasına sebebiyet vermesinden dolayı düzgün bir şekilde teşhis edilememesi sonucunu doğurmaktadır. Önerilen yöntemde ise bu istatistiki değerleri kullanmak zorunda kalmadan daha doğru bir şekilde aykırı değerlerin teşhis edilebilmesi mümkün olmaktadır. Önerilen metotta kullanılan istasyona ait $\mathrm{m}$ adet veri olduğunu varsayalım. Bu veriler $\left(\mathrm{Q}_{1}\right.$, $\mathrm{Q}_{2}, \ldots \mathrm{Q}_{\mathrm{m}}$ ) olacak şekilde küçükten büyüğe doğru sıralanır. En küçük veriye $\mathrm{T}=1$, en büyük veriye $\mathrm{T}=\mathrm{n}$ olacak şekilde birer artan değerler verilir. En küçük veriden en büyük veriye kadar sırasıyla çalışmada geliştirilen (6) numaralı eşitlik yardımı ile $\alpha$ değerleri hesaplanır.

$\alpha=\frac{Q_{m}}{T_{m} \cdot \ln T_{m}}$

Bulunan bu değerler yardımıyla $\alpha$-T grafikleri çizilir. Grafik üzerinden $\alpha$ değerlerinin içinde $\alpha_{\text {min }}$ değerinin olduğu nokta bulunur ve bu noktadan sonra $\alpha$ değerlerinin artış gösterdiği bir nokta mevcut ise $\alpha_{\text {min }}$ değerinin olduğu noktadan sonraki değerlerin aykırı değer oldukları kabul edilir. Bu noktadan sonra aykırı değer olarak kabul edilen noktalar için yeni $\alpha$ değerleri (7) nolu eşitlik yardımı ile yeniden hesaplanarak grafiğin doğal eğimine uygun şekle getirilir.

$\alpha_{T m}=\frac{\alpha_{\min }}{T_{m}} T_{\min }$

Aykırı değer olarak kabul edilen bu noktaların düzeltilmiş değerleri çalışmada geliştirilen (8) numaralı eşitlik yardımıyla hesaplanır ve grafiğin doğal eğimine uyacak şekilde yeniden hesaplanırlar. Yine aynı şekilde kullanılmış olan bu formül yardımıyla 50, 100, 1000 ve 10000yıllık taşkınlar grafiğin doğal eğimine uyacak şekilde hesaplanabilmektedir.

$Q_{m}=\alpha_{\min } \cdot T_{m} \cdot \ln T_{m}$

$\mathrm{Bu}$ yöntem sayesinde veri içerisindeki aykırı değerler elimine edildiğinden taşkın frekans analiz sonuçlarındaki aykırı değerlerin etkilerinden doğan hatalar giderilmiş ve daha doğru sonuçlar elde edilmiş olur.

\section{TAŞKIN FREKANS ANALIZI}

Taşkın frekans analizi, belirli bir periyotta, belirlenen bir debinin üzerindeki bir taşkın debisinin gelme olasılığının analizidir.

Taşkın frekans analizinde ele alınacak veriler homojen ve bağımsız olmalıdır. Homojenlik özelliği, bir serideki tüm gözlem değerlerinin aynı topluma ait olduğunu gösterir. Gelecekte 
meydana gelecek hidrolojik olayların frekansının tahmininde homojenlik şartı, eldeki verilerin gelecekteki akımları temsil etmesini şart koşar. Bağımsızlık özelliği ise, bir hidrolojik olayda, örneğin bir tekil büyük fırtına sisteminin meydana getirdiği iki veya daha fazla taşkın piklerinden sadece bir tanesinin veri grubuna girmesidir [6].

Taşkın frekans analizi prosedürü, bölgedeki taşkın popülâsyonunun uygun istatistikî dağılımının ve uygun parametre tahmin metodunun belirlenmesi ile ilgilenir. Taşkın frekans analiz yöntemleri üzerine yapılan son araştırmaların çoğu bir D/E yöntem terminolojisi içinde dağılım (D) ve tahmin (E) yöntemlerinin doğru seçimi üzerine yoğunlaşmıştır. Özel bir D/E yöntemi uygulanırken iki bileşen hesaba katılmalıdır: tanımlanabilirlik ve tahmin edilebilirlik [7].Tanımlanabilirlik, seçilen istatistiksel veri karakteristiklerinin yeniden üretilmesi için bir dağılımın bulunması ile ilgilidir. Özellikle eğrilik ve kurtosis ölçümleri ile açıklanan yoğunluk şeklinin tanımlanması ile ilgilidir. Tahmin edilebilirlik ise, taşkın hesabındaki hatayı hesaplamak için kullanılan taraflılık ve ortalama korelasyon katsayısı hatasıyla ölçülebilecek doğrulukla ilgilidir [8].

Hem üst dağılımın dikkate alınması fikri hem de parametre tahmini prosedürü (D/E), yıllık maksimum taşkınlar için bir üst dağılımın belirlenmesinin mümkün olmadığ 1 argümanına dayanır [9].

\subsection{Noktasal Taşkın Frekans Analizi}

Belirli tekerrür aralığında meydana gelebilecek olan taşkın debisinin hesaplanması için en uygun olasılık yoğunluk fonksiyonunun belirlenmesi gerekmektedir. Bu O.Y.F. belirlenirken Kolmogorov Smirnov, Anderson Darling ve Ki Kare gibi uyumun iyiliği testleri kullanılarak seçilen veri setine ait en uygun O.Y.F. belirlenir. Belirlenen en uygun O.Y.F. kullanılarak taşkın debileri hesaplanır.

\subsection{Momentlere Dayalı Taşkın Frekans Analizi}

Hosking tarafından 1990 yılında öne sürülen L momentler yöntemi parametre tahmini, bölgeselleştirme ve dağılım tanımlama ile ilgili çeşitli problemleri çözmede yaygın olarak kullanılmaktadır [10]. L momentler yöntemi olasılık ağırlıklı momentlerin doğrusal bileşimidir. Bu nedenle L momentler yöntemi ile hesaplamalar yapılırken kullanılan verilerin karesi ve küpü alınmamaktadır. Bu sayede elde edilen çarpıklık ve varyans katsayıları daha tarafsız bir şekilde hesaplanmaktadır ve hemen hemen normal dağılıma sahip olmaktadır [11]. L moment oranları, çarpıklık ve basıklık gibi parametrelerin hesabı aşağıdaki gibidir;

Ortalama $=\mathrm{L}_{1}$

L-Cv(Varyasyon Katsayısı) $\left(\mathrm{t}_{2}\right)$ :

$\mathrm{t}_{2}=\mathrm{L}_{2} / \mathrm{L}_{1}$

L-Çarpıklık ( $\left.\mathrm{t}_{3}\right)$ :

$\mathrm{t}_{3}=\mathrm{L}_{3} / \mathrm{L}_{2}$ 
L-Basıklık $\left(\mathrm{t}_{4}\right)$ :

$\mathrm{t}_{4}=\mathrm{L}_{4} / \mathrm{L}_{2}$

Burada:

$\mathrm{L}_{1}=\beta_{0}$

$\mathrm{L}_{2}=2 \beta_{1}-\beta_{0}$

$\mathrm{L}_{3}=6 \beta_{2}-6 \beta_{1}+\beta_{0}$

$\mathrm{L}_{4}=20 \beta_{3}-30 \beta_{2}+12 \beta_{1}-\beta_{0}$

Burada veri ( $\left.\mathrm{x}_{1: \mathrm{n}}\right) 1$ den n’e kadar artan sıralı olacak şekilde sıralandığında:

$\beta_{0}=\mathrm{n}^{-1} \sum_{j=1}^{n} x_{j}$

$\beta_{1}=\mathrm{n}^{-1} \sum_{j=2}^{n} x_{j}[(\mathrm{j}-1) /(\mathrm{j}-2)]$

$\beta_{2}=\mathrm{n}^{-1} \sum_{j=3}^{n} x_{j}[(\mathrm{j}-1)(\mathrm{j}-2)] /[(\mathrm{n}-1)(\mathrm{n}-2)]$

$\beta_{3}=\mathrm{n}^{-1} \sum_{j=4}^{n} x_{j}[(\mathrm{j}-1)(\mathrm{j}-2)(\mathrm{j}-3)] /[(\mathrm{n}-1)(\mathrm{n}-2)(\mathrm{n}-3)]$

şeklinde hesaplanmaktadır [12].

Yukarıda belirtilen eşitlikler yardımı ile hesaplanan L moment oranları kullanılarak x test programı kullanılarak aşağıdaki hesaplamalar sırasıyla yapılmaktadır.

Seçilen her bir istasyon için uyumsuzluk ölçüsü $\mathrm{D}_{\mathrm{i}}$ hesaplanmaktadır. Hesaplanan değerler seçilen istasyon sayısına bağlı olarak belirlenen kritik değerden büyük ise seçilen istasyonun uyumsuz olduğu belirlenir.

Frekans analizinde kullanılacak O.Y.F. ait parametreler bölgesel olarak hesaplanmaktadır.

Seçilen bölge için heterojenlik ölçüsü $(\mathrm{H})$ hesaplanmaktadır. Hesaplanan $\mathrm{H}<1$ ise kabul edilebilir düzeyde homojendir, eğer $1 \leq \mathrm{H}<2$ ise muhtemelen heterojendir ve $\mathrm{H}>2$ ise bölge kesinlikle heterojendir. 
Belirlenen dağılımlar içinde en uygun dağılımın bulunabilmesi için dağılım uygunluk ölçüsü (Z) hesaplanmaktadır. Hesaplanan $\mathrm{Z}$ değerlerine bakılarak 1.68 değerine eşit veya küçük hesaplanan olasılık dağılım fonksiyonları en uygun dağılım olarak belirlenir[10-13].

\section{MATERYAL}

Bu çalışmada materyal olarak Elektrik İşleri Etüd İdaresi'nin (EİEİ) ve Devlet Su İşleri’nin (DSİ) yıllara göre çıkarmış olduğu akım rasat yıllıklarındaki su yılı maksimum akım değerleri kullanılmıştır. Fırat havzasındaki 6 adet gözlem istasyonuna ait yıllık maksimum akış verilerinden faydalanılmıştır. Fırat havzasındaki istasyonlara ait bazı bilgiler tablo 1'de verilmiştir. Gözlem istasyonlarının coğrafi konumu şekil 1'de gösterilmektedir.

Tablo 1. Firat Havzasında Bulunan Gözlem İstasyonlarına Ait Bilgiler

\begin{tabular}{|l|c|l|c|c|c|}
\hline \multicolumn{1}{|c|}{ İstasyon Adı } & No & Suyun Adı & $\begin{array}{c}\text { Gözlem } \\
\text { Süresi } \\
(\mathbf{y l l})\end{array}$ & $\begin{array}{c}\text { Yağış } \\
\text { Alanı } \\
\mathbf{( k m}^{\mathbf{2}}\end{array}$ & $\begin{array}{c}\text { Kot } \\
(\mathbf{m})\end{array}$ \\
\hline Selenk Köprüsü & $21-041$ & Perisuyu & 22 & 2062 & 1154 \\
\hline Kemah Boğazı & 2119 & Frrat Nehri & 27 & 10356 & 1123 \\
\hline Tutak & 2122 & Murat Nehri & 31 & 5882.4 & 1552 \\
\hline Yazıköy & 2124 & Tohma Suyu & 37 & 1256.1 & 1193 \\
\hline Melekbahçe & 2133 & Munzur Suyu & 31 & 3284.8 & 875 \\
\hline Dedikuşağı & 2147 & Munzur Suyu & 34 & 875 & 1195 \\
\hline
\end{tabular}

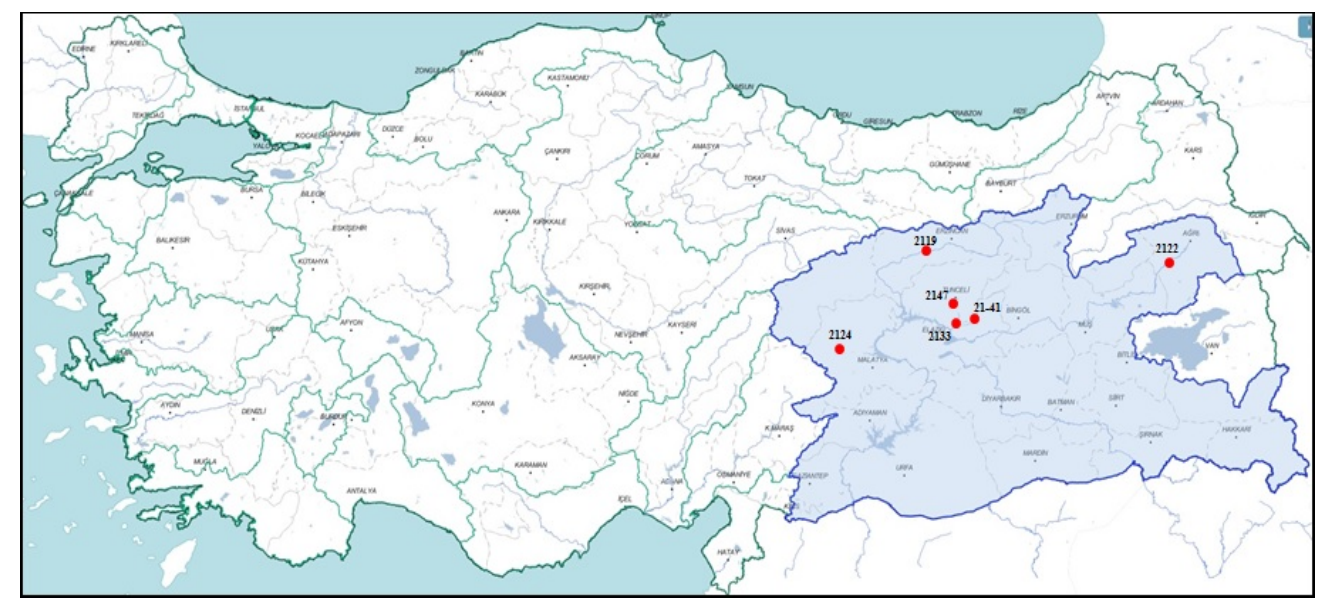

Şekil 1. Akım gözlem istasyonlarının coğrafi konumları 


\section{UYGULAMA}

Çalışmada kullanılan Fırat Havzasında bulunan gözlem istasyonlarına ait ortalama, standart sapma ve çarpıklık gibi istatistiki büyüklükler hem veri setleri aykırı değerlerin etkisi altında iken hem de veri setlerinde bulunan aykırı değerler önermiş olduğumuz yöntem ile grafiğin doğal eğimine uyacak şekilde belirlendikten sonra düzeltilen veri setleri kullanılarak hesaplanmıştır.

Aykırı değerler veri setinde iken ve aykırı değerlerin etkisi giderildikten sonra hesaplanan istatistiki büyüklükler tablo 2'de gösterilmektedir.

Tablo 2. Gözlem istasyonlarına ait Ortalama, Standart Sapma ve Çarpıklık Değerleri

\begin{tabular}{|c|c|c|c|c|c|}
\hline İstasyon Adı & No & $\begin{array}{c}\text { Gözlem } \\
\text { Süresi (yıl) }\end{array}$ & Ortalama & $\begin{array}{l}\text { Standart } \\
\text { Sapma }\end{array}$ & Çarpıklık \\
\hline Selenk Köprüsü & \multirow{2}{*}{$\begin{array}{l}21- \\
041\end{array}$} & \multirow[b]{2}{*}{22} & 283.864 & 155.502 & 2.204 \\
\hline Selenk Köprüsü* & & & 263.084 & 100.240 & 0.768 \\
\hline \multicolumn{3}{|c|}{ Fark } & 20.780 & 55.262 & 1.436 \\
\hline \multicolumn{3}{|c|}{ Hata \% } & 7.320 & 35.538 & 65.154 \\
\hline Kemah Boğazı & \multirow{2}{*}{2119} & \multirow{2}{*}{27} & 485.007 & 203.459 & 1.424 \\
\hline Kemah Boğazi* & & & 464.465 & 153.292 & 0.157 \\
\hline \multicolumn{3}{|c|}{ Fark } & 20.542 & 50.167 & 1.267 \\
\hline \multicolumn{3}{|c|}{ Hata \% } & 4.235 & 24.657 & 88.975 \\
\hline Tutak & \multirow{2}{*}{2122} & \multirow{2}{*}{31} & 543.516 & 210.997 & 0.303 \\
\hline Tutak* & & & 537.411 & 202.246 & 0.230 \\
\hline \multicolumn{3}{|c|}{ Fark } & 6.105 & 8.751 & 0.073 \\
\hline \multicolumn{3}{|c|}{ Hata \% } & 1.123 & 4.147 & 24.092 \\
\hline Yazıköy & \multirow{2}{*}{2124} & \multirow{2}{*}{37} & 46.481 & 21.605 & 0.264 \\
\hline Yazıköy* & & & 45.404 & 19.271 & 0.140 \\
\hline \multicolumn{3}{|c|}{ Fark } & 1.077 & 2.334 & 0.124 \\
\hline \multicolumn{3}{|c|}{ Hata \% } & 2.317 & 10.803 & 46.970 \\
\hline Melekbahçe & \multirow{2}{*}{2133} & \multirow{2}{*}{31} & 547.129 & 220.381 & 0.867 \\
\hline Melekbahçe* & & & 535.376 & 190.360 & 0.057 \\
\hline \multicolumn{3}{|c|}{ Fark } & 11.753 & 30.021 & 0.81 \\
\hline \multicolumn{3}{|c|}{ Hata \% } & 2.148 & 13.622 & 93.426 \\
\hline Dedikuşağı & \multirow{2}{*}{2147} & \multirow{2}{*}{34} & 167.177 & 58.761 & 0.660 \\
\hline Dedikuşağı* & & & 164.810 & 52.768 & 0.046 \\
\hline \multicolumn{3}{|c|}{ Fark } & 2.367 & 5.993 & 0.614 \\
\hline \multicolumn{3}{|c|}{ Hata $\%$} & 1.416 & 10.199 & 93.030 \\
\hline
\end{tabular}

* ile gösterilenler aykırı değerler önerilen yöntemle çıkarıldıktan sonra hesaplanan değerleri göstermektedir. 
Tablo 2'den de görülebileceği gibi aykırı değerler önerilen yöntemle grafiğin doğal eğimine uyacak şekilde yeniden hesaplandığında veri setine ait istatistiki büyüklüklerde belirgin bir düşüş meydana gelmektedir. Bu nedenle yapılacak olan hesaplamalarda aykırı değerlerin etkisinin göz ardı edilmesi yanlış sonuçlara ve yorumlara neden olabileceği düşünülmektedir. Dolayısıyla ortalama, standart sapma ve çarpıklık gibi istatistiki büyüklükler yardımı ile aykırı değerleri teşhis için kullanılan yöntemlerde sonuçların ve yorumların hatalı olmasına yol açabilirler.

Önerilen yöntemle hesap yapılması durumunda ise çizilen $\alpha-\mathrm{T}$ grafiklerinde $\alpha$ min değerinden sonraki değerlerin aykırı davranış gösterdiği kabul edilmektedir. Aşağıdaki şekillerde verilerini kullanmış olan istasyonların $\alpha$-T grafikleri ve bu grafik üzerinde $\alpha$ min değerleri ve aykırı değerlerin hangi veriler olduğu gösterilmiştir.

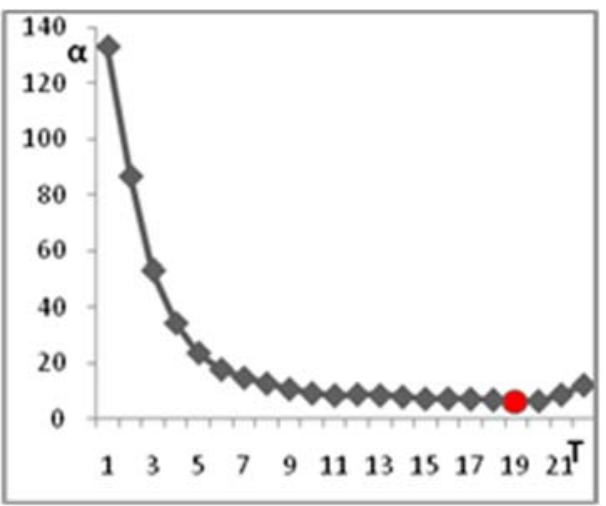

Şekil 2. Firat 2119 nolu istasyonu önerilen yöntem için $\alpha$-T diyagramı

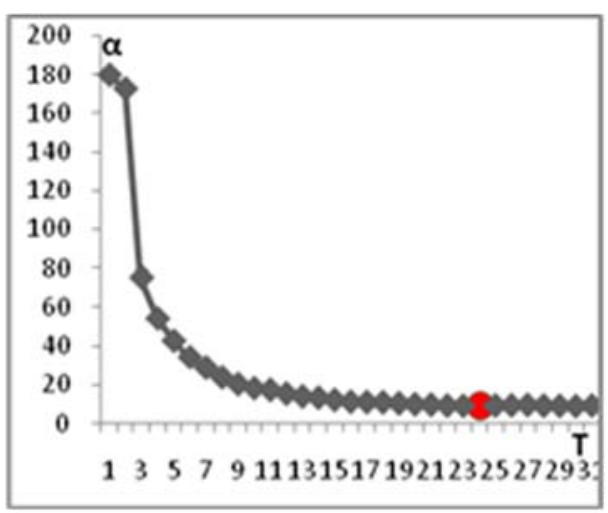

Şekil 4. Fırat 2122 nolu istasyonu önerilen yöntem için $\alpha$-T diyagramı

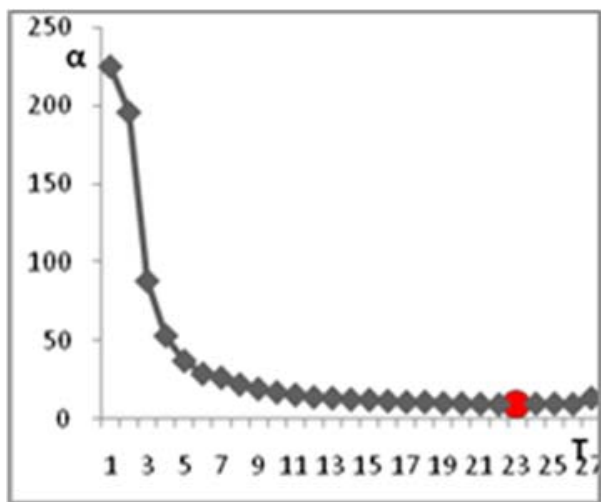

Şekil 3. Furat 21-041 nolu istasyonu önerilen yöntem için $\alpha$-T diyagramı

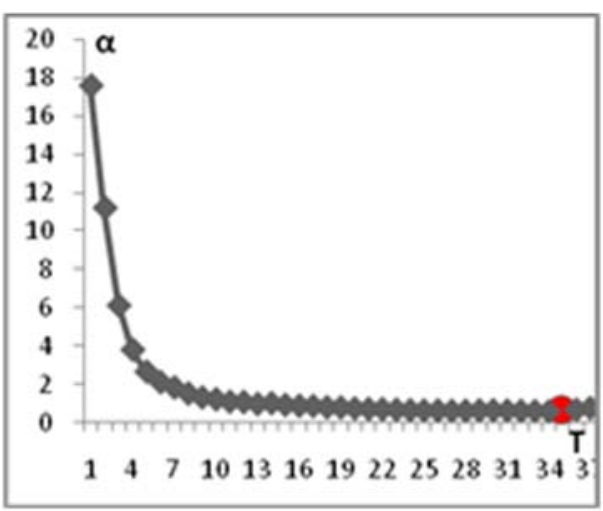

Şekil 5. Fırat 2124 nolu istasyonu önerilen yöntem için $\alpha$-T diyagramı 


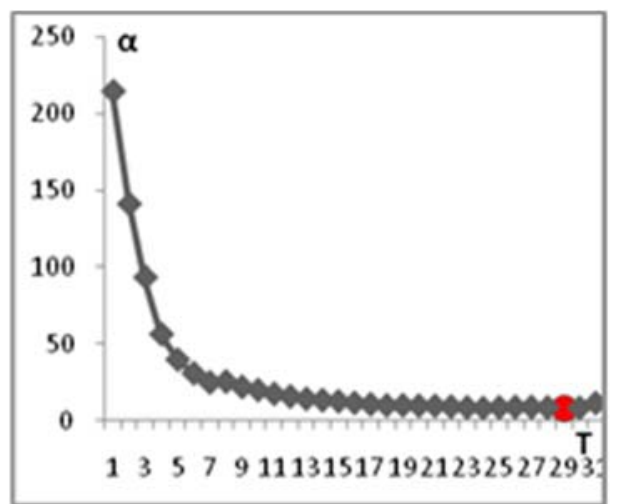

Şekil 6. Furat 2133 nolu istasyonu önerilen yöntem için $\alpha$-T diyagramı

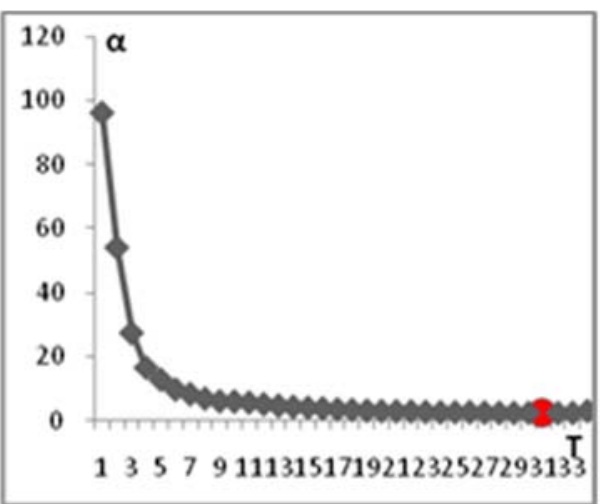

Şekil 7. Firat 2147 nolu istasyonu önerilen yöntem için $\alpha$-T diyagramı

Yukarıda verilen $\alpha-T$ grafikleri incelendiğinde Fırat 21-041 nolu istasyon için. $\alpha_{\min } 19$ nolu ölçümde, Fırat 2119 nolu istasyon için $\alpha_{\text {min }} 23$ nolu ölçümde, Fırat 2122 nolu istasyon için $\alpha_{\text {min }} 24$ nolu ölçümde, Fırat 2124 nolu istasyon için $\alpha_{\min } 35$ nolu ölçümde, Frrat 2133 nolu istasyon için $\alpha_{\min } 29$ nolu ölçümde, Frrat 2147 nolu istasyon için $\alpha_{\min } 31$ nolu ölçümde bulunmuştur. Bu noktalardan sonraki değerlerin aykırı değer olduğu kabul edilmiştir.

Aykırı değer olarak davrandığı kabul edilen bu değerler önerilen (7) numaralı eşitlik yardımı ile düzeltilerek grafiğin doğal eğimine uygun forma getirilmektedir. Aynı şekilde grafiğin doğal eğimine uygun bir şekilde uzatılması sonucu 50, 100, 1000 ve 10000 yılda gelecek olan taşkın debileri de aykırı değerlerin etkisinden arındırılmış bir biçimde hesaplanmaktadır.

Aşağıda Fırat havzası üzerinde bulunan gözlem istasyonlarına ait veriler kullanılarak taşkın debilerinin hesabı hem önerilen yöntem ile hem de bu verilere en uygun olan olasılık dağılım fonksiyonları yardımı ile hesaplanmıştır. En uygun olasılık dağılım fonksiyonları belirlenirken Kolmogorov Smirnov, Anderson Darling ve Ki Kare uyumun iyiliği testleri sonucu en uygun ilk üç olasılık dağılım fonksiyon sonuçlarına yer verilmiştir.

Seçilen istasyonlar için aykırı değerler veri setlerinden çıkarıldıktan sonra 61 adet olasılık yoğunluk fonksiyonu içerisinden Kolmogorov Smirnov, Anderson Darling ve Ki Kare uyumun iyiliği testlerine göre en uygun dağılımlar aşağıdaki gibi belirlenmiştir. 
Tablo 3. 21-041 nolu istasyon için en uygun olasılık yoğunluk fonksiyonları

\begin{tabular}{|l|l|l|l|}
\hline O.Y.F. & Kolmogorov Smirnov & Anderson Darling & Ki-Kare \\
\hline GumbelMax. & 1 & 3 & 36 \\
\hline Frechet (3P) & 2 & 2 & 39 \\
\hline Johnson SB & 3 & 5 & 35 \\
\hline Pearson 5 (3P) & 14 & 1 & 38 \\
\hline Exponential (2P) & 47 & 44 & 1 \\
\hline PowerFunction & 48 & 45 & 2 \\
\hline Rayleight & 38 & 36 & 3 \\
\hline
\end{tabular}

Tablo 4. Fırat 21-041 nolu istasyon için uygunluk test sonuçlarının analiz sonuçları ve önerilen yöntem dĕgerleri

\begin{tabular}{|l|l|l|l|l|}
\hline & $\mathrm{Q}_{50}$ & $\mathrm{Q}_{100}$ & $\mathrm{Q}_{1000}$ & $\mathrm{Q}_{10.000}$ \\
\hline GumbelMax. & 521.85 & 577.19 & 760.04 & 942.58 \\
\hline Frechet (3P) & 522.35 & 577.65 & 760.4 & 942.82 \\
\hline Johnson SB & 518.13 & 570.84 & 745.81 & 925.37 \\
\hline Pearson 5 (3P) & 510.7 & 562.83 & 740.7 & 932.58 \\
\hline Exponential (2P) & 719.4 & 829.15 & 1193.7 & 1558.3 \\
\hline PowerFunction & 551.12 & 562.03 & 571.98 & 572.98 \\
\hline Rayleight & 576.55 & 625.54 & 766.13 & 884.65 \\
\hline Önerilen Yöntem & 465.0 & 547.4 & 821.1 & 1094.8 \\
\hline
\end{tabular}

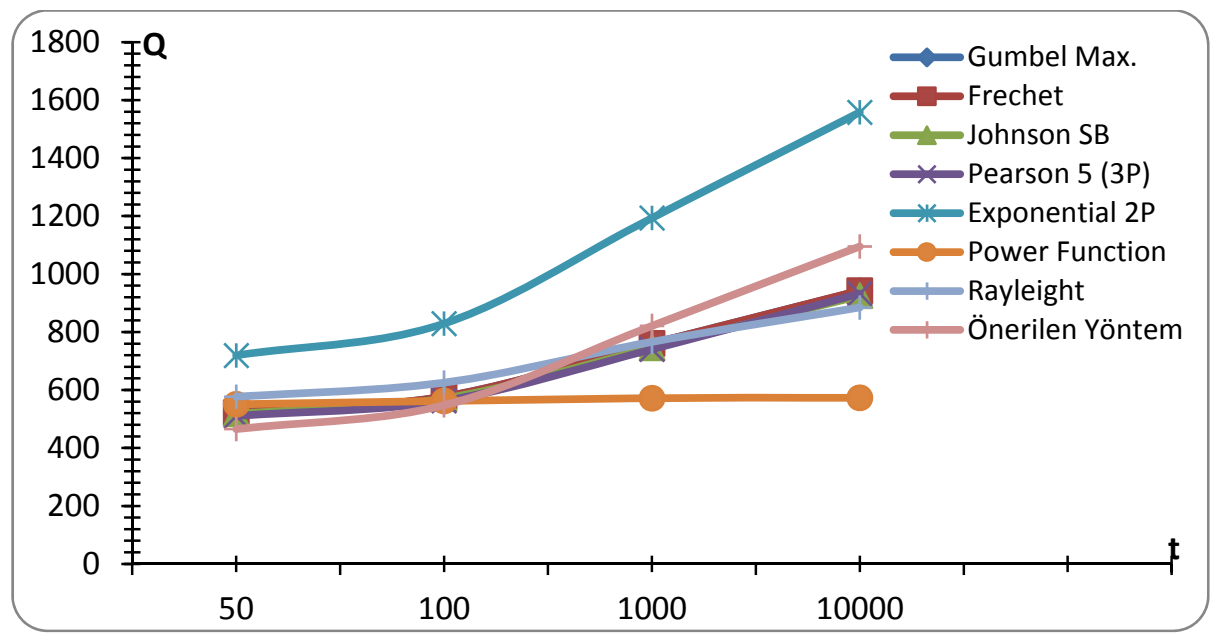

Şekil 8. Firat 21-041 nolu istasyon için Q-T grafiği 
Tablo 5. 2119 nolu istasyon için en uygun olasılık yoğunluk fonksiyonları

\begin{tabular}{|c|c|c|c|}
\hline O.Y.F. & Kolmogorov Smirnov & Anderson Darling & Ki-Kare \\
\hline Log- Pearson 3 & 1 & 2 & 1 \\
\hline Gen. Ext. Value & 2 & 1 & 10 \\
\hline Weibull (3P) & 3 & 7 & 25 \\
\hline Johnson SB & 4 & 3 & 2 \\
\hline Log-Logistic & 29 & 31 & 3 \\
\hline
\end{tabular}

Tablo 6. Fırat 2119 nolu istasyon için uygunluk test sonuçlarının analiz sonuçları ve önerilen yöntem değerleri

\begin{tabular}{|l|c|c|c|c|}
\hline & $\mathrm{Q}_{50}$ & $\mathrm{Q}_{100}$ & $\mathrm{Q}_{1000}$ & $\mathrm{Q}_{10.000}$ \\
\hline Log- Pearson 3 & 821.69 & 876.25 & 1029.3 & 1151.9 \\
\hline Gen. Ext. Value & 837.11 & 896.68 & 1061 & 1184.7 \\
\hline Weibull (3P) & 798.62 & 846.52 & 980.63 & 1090.5 \\
\hline Johnson SB & 795.45 & 830.12 & 905.52 & 946.6 \\
\hline Log-Logistic & 1018.3 & 1193.5 & 2011.1 & 3382.6 \\
\hline Önerilen Yöntem & 787.3 & 926.8 & 1390.2 & 1853.5 \\
\hline
\end{tabular}

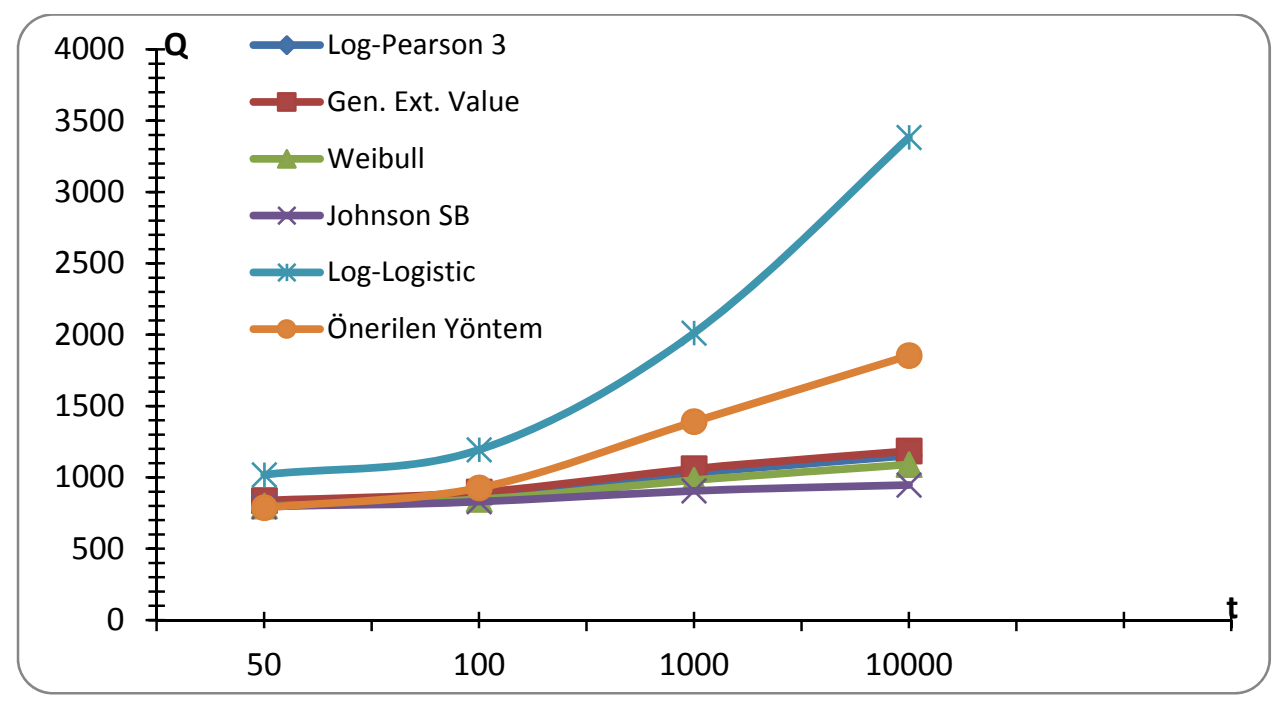

Şekil 9. Fırat 2119 nolu istasyon için Q-T grafiği 
Tablo 7. 2122 nolu istasyon için en uygun olasılık yoğunluk fonksiyonları

\begin{tabular}{|l|l|l|l|}
\hline O.Y.F. & Kolmogorov Smirnov & Anderson Darling & Ki-Kare \\
\hline Gen. Gamma & 1 & 9 & 7 \\
\hline Gamma & 2 & 14 & 16 \\
\hline Inv. Gaussian & 3 & 32 & 12 \\
\hline Gen. Ext. Value & 7 & 1 & 29 \\
\hline Log-Logistic (3P) & 9 & 2 & 1 \\
\hline Gamma (3P) & 12 & 3 & 27 \\
\hline Fatigue Life (3P) & 13 & 4 & 2 \\
\hline Lognormal (3P) & 14 & 5 & 3 \\
\hline
\end{tabular}

Tablo 8. Fırat 2122 nolu istasyon için uygunluk test sonuçlarının analiz sonuçlarl ve önerilen yöntem değerleri

\begin{tabular}{|l|l|l|l|l|}
\hline & $\mathrm{Q}_{50}$ & $\mathrm{Q}_{100}$ & $\mathrm{Q}_{1000}$ & $\mathrm{Q}_{10.000}$ \\
\hline Gen. Gamma & 1078.4 & 1174.4 & 1471.4 & 1747.9 \\
\hline Gamma & 1058.8 & 1150.2 & 1431.9 & 1692.9 \\
\hline Inv. Gaussian & 1093.4 & 1205.7 & 1571 & 1931.4 \\
\hline Gen. Ext. Value & 1045.6 & 1121.9 & 1327.6 & 1477.2 \\
\hline Log-Logistic (3P) & 1113.3 & 1252.4 & 1801.5 & 2522.3 \\
\hline Gamma (3P) & 1022.8 & 1099.7 & 1329.7 & 1535.3 \\
\hline Fatigue Life (3P) & 1022.2 & 1099.5 & 1332.1 & 1542 \\
\hline Lognormal (3P) & 1021.3 & 1098.8 & 1333.7 & 1548 \\
\hline Önerilen Yöntem & 829.7 & 976.7 & 1465 & 1953.3 \\
\hline
\end{tabular}

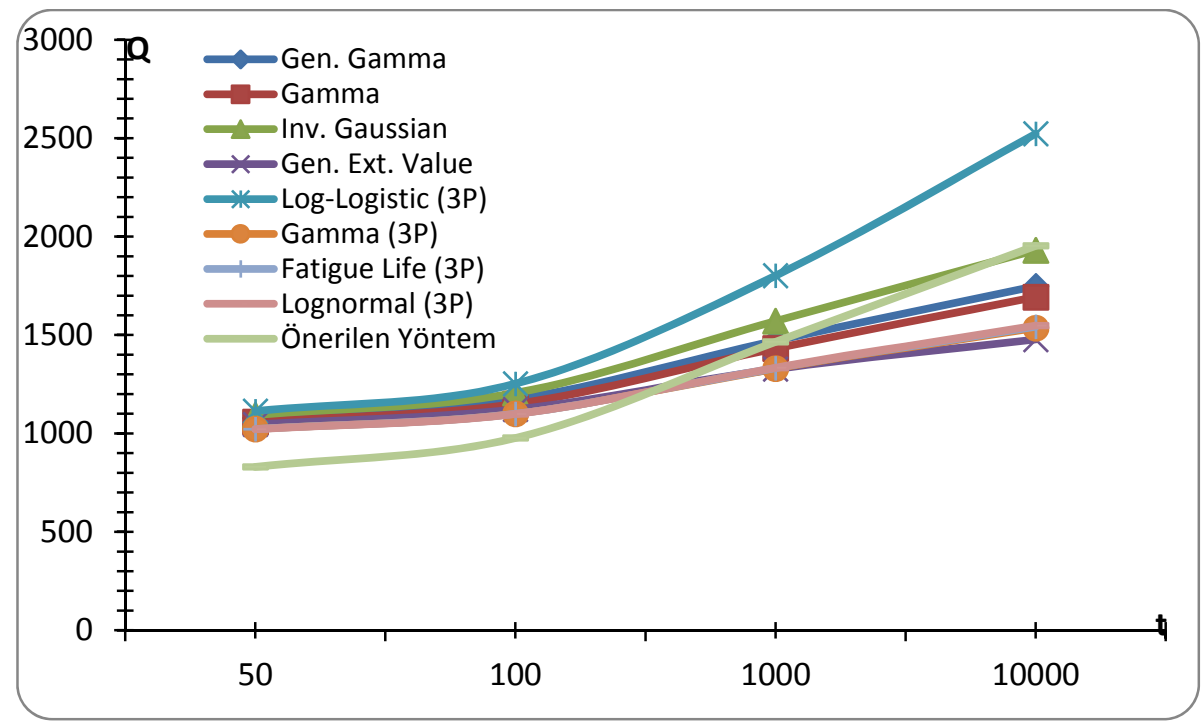

Şekil 10. Fırat 2122 nolu istasyon için Q-T grafiği 
Tablo 9. 2124 nolu istasyon için en uygun olasılık yoğunluk fonksiyonları

\begin{tabular}{|l|l|l|l|}
\hline \multicolumn{1}{|c|}{ O.Y.F. } & Kolmogorov Smirnov & Anderson Darling & Ki-Kare \\
\hline Nakagami & 1 & 3 & 15 \\
\hline Johnson SB & 2 & 1 & 22 \\
\hline Pearson 6 & 3 & 12 & 32 \\
\hline Pert & 8 & 2 & 1 \\
\hline Beta & 20 & 4 & 2 \\
\hline Rice & 10 & 24 & 3 \\
\hline
\end{tabular}

Tablo 10. Fırat 2124 nolu istasyon için uygunluk test sonuçlarının analiz sonuçları ve önerilen yöntem dĕgerleri

\begin{tabular}{|l|l|l|l|l|}
\hline & $\mathrm{Q}_{50}$ & $\mathrm{Q}_{100}$ & $\mathrm{Q}_{1000}$ & $\mathrm{Q}_{10.000}$ \\
\hline Nakagami & 96.58 & 104.23 & 126.16 & 144.66 \\
\hline Johnson SB & 97.69 & 104.88 & 123.05 & 135.22 \\
\hline Pearson 6 & 100.59 & 110.69 & 142.3 & 172.06 \\
\hline Pert & 97.135 & 103.58 & 118.5 & 127.07 \\
\hline Beta & 96.563 & 101.72 & 112.03 & 116.63 \\
\hline Rice & 91.751 & 98.473 & 117.5 & 133.3 \\
\hline Önerilen Yöntem & 81.1 & 95.5 & 143.2 & 190.9 \\
\hline
\end{tabular}

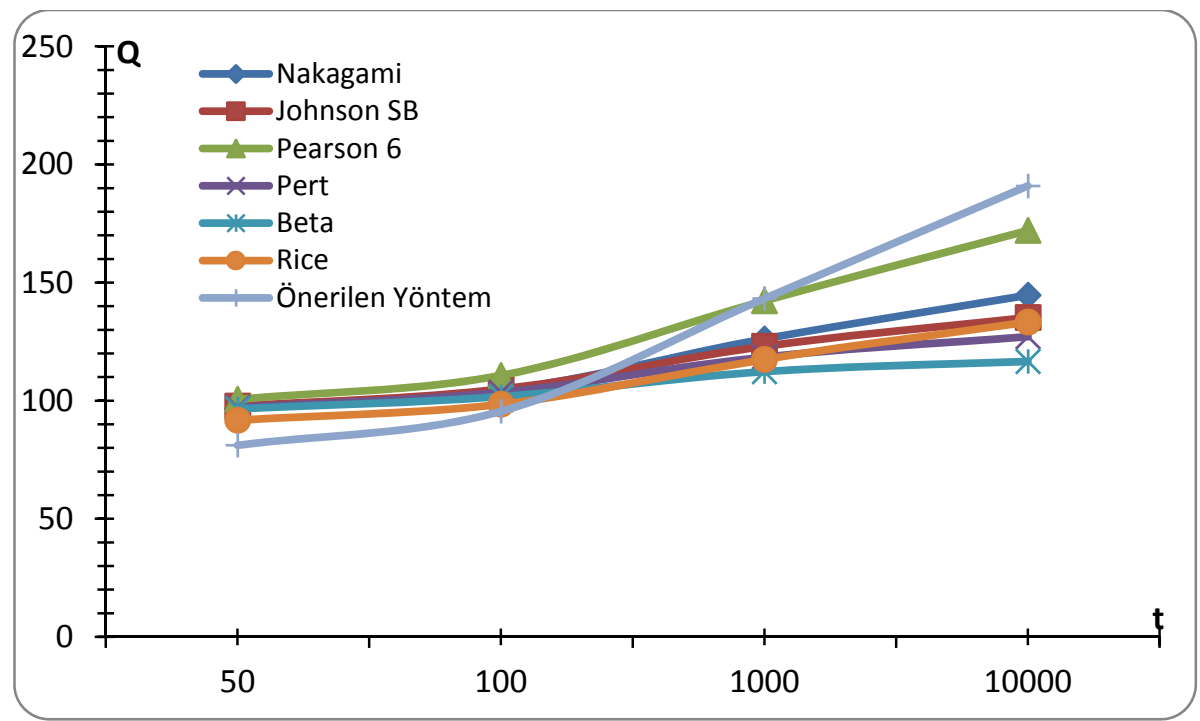

Şekil 11. Firat 2124 nolu istasyon için Q-T grafiği 
Tablo 11. 2133 nolu istasyon için en uygun olasılık yoğunluk fonksiyonları

\begin{tabular}{|l|l|l|l|}
\hline \multicolumn{1}{|c|}{ O.Y.F. } & Kolmogorov Smirnov & Anderson Darling & Ki-Kare \\
\hline Gamma (3P) & 1 & 2 & 11 \\
\hline Pearson 5 (3P) & 2 & 14 & 10 \\
\hline Nakagami & 3 & 19 & 20 \\
\hline Gen. Ext. Value & 7 & 1 & 3 \\
\hline Log-Logistic (3P) & 5 & 3 & 17 \\
\hline Laplace & 24 & 27 & 2 \\
\hline Rice & 29 & 24 & 1 \\
\hline
\end{tabular}

Tablo 12. Fırat 2133 nolu istasyon için uygunluk test sonuçlarının analiz sonuçlart ve önerilen yöntem değerleri

\begin{tabular}{|l|l|l|l|l|}
\hline & $\mathrm{Q}_{50}$ & $\mathrm{Q}_{100}$ & $\mathrm{Q}_{1000}$ & $\mathrm{Q}_{10.000}$ \\
\hline Gamma (3P) & 922.86 & 981.67 & 1152.8 & 1300.9 \\
\hline Pearson 5 (3P) & 925.05 & 986.62 & 1168.6 & 1329.7 \\
\hline Nakagami & 911.8 & 968.46 & 1130.9 & 1268 \\
\hline Gen. Ext. Value & 910.13 & 953.82 & 1053.9 & 1109.6 \\
\hline Log-Logistic (3P) & 947.46 & 1029.1 & 1307.7 & 1601.7 \\
\hline Laplace & 941.08 & 1030.8 & 1329 & 1627.1 \\
\hline Rice & 883.14 & 933.6 & 1075.5 & 1192.9 \\
\hline Önerilen Yöntem & 943.4 & 1110.5 & 1665.8 & 2221 \\
\hline
\end{tabular}

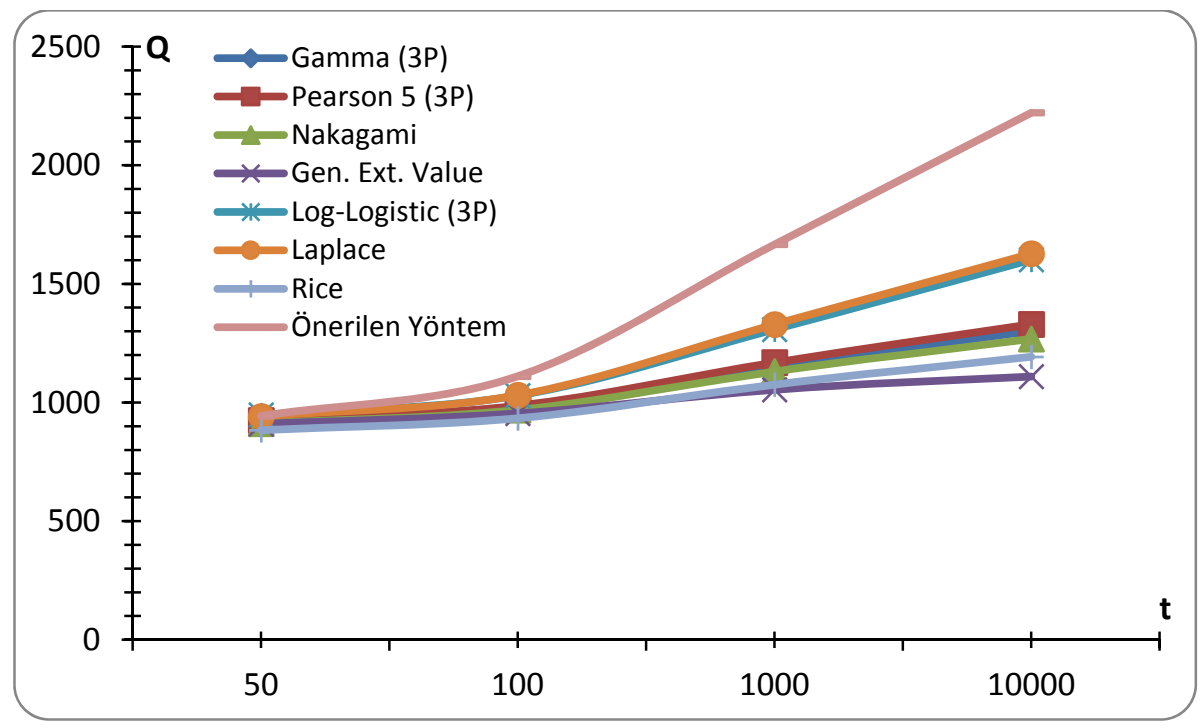

Şekil 12. Fırat 2133 nolu istasyon için Q-T grafiği 
Tablo 13. 2147 nolu istasyon için en uygun olasılık yoğunluk fonksiyonları

\begin{tabular}{|l|l|l|l|}
\hline \multicolumn{1}{|c|}{ O.Y.F. } & KolmogorovSmirnov & AndersonDarling & \multicolumn{1}{c|}{ Ki-Kare } \\
\hline Ki Kare (2P) & 1 & 4 & 7 \\
\hline Burr & 2 & 1 & 26 \\
\hline Normal & 3 & 14 & 3 \\
\hline Gen.Ext. Value & 6 & 2 & 10 \\
\hline Johnson SU & 4 & 3 & 11 \\
\hline Weibull & 8 & 24 & 1 \\
\hline Nakagami & 19 & 10 & 2 \\
\hline
\end{tabular}

Tablo 14. Fırat 2147 nolu istasyon için uygunluk test sonuçlarının analiz sonuçlart ve önerilen yöntem değerleri

\begin{tabular}{|l|l|l|l|l|}
\hline & $\mathrm{Q}_{50}$ & $\mathrm{Q}_{100}$ & $\mathrm{Q}_{1000}$ & $\mathrm{Q}_{10.000}$ \\
\hline Ki Kare (2P) & 286.64 & 303.01 & 349.45 & 388.27 \\
\hline Burr & 302.83 & 329.28 & 423.63 & 535.09 \\
\hline Normal & 287.86 & 303.87 & 348.76 & 385.71 \\
\hline Gen.Ext. Value & 302.43 & 322.56 & 376.23 & 414.54 \\
\hline Johnson SU & 307.56 & 333.61 & 418.54 & 504.39 \\
\hline Weibull & 273.35 & 287.22 & 324.83 & 354.46 \\
\hline Nakagami & 303.61 & 324.05 & 382.66 & 432.13 \\
\hline Önerilen Yöntem & 266.6 & 313.8 & 470.7 & 627.6 \\
\hline
\end{tabular}

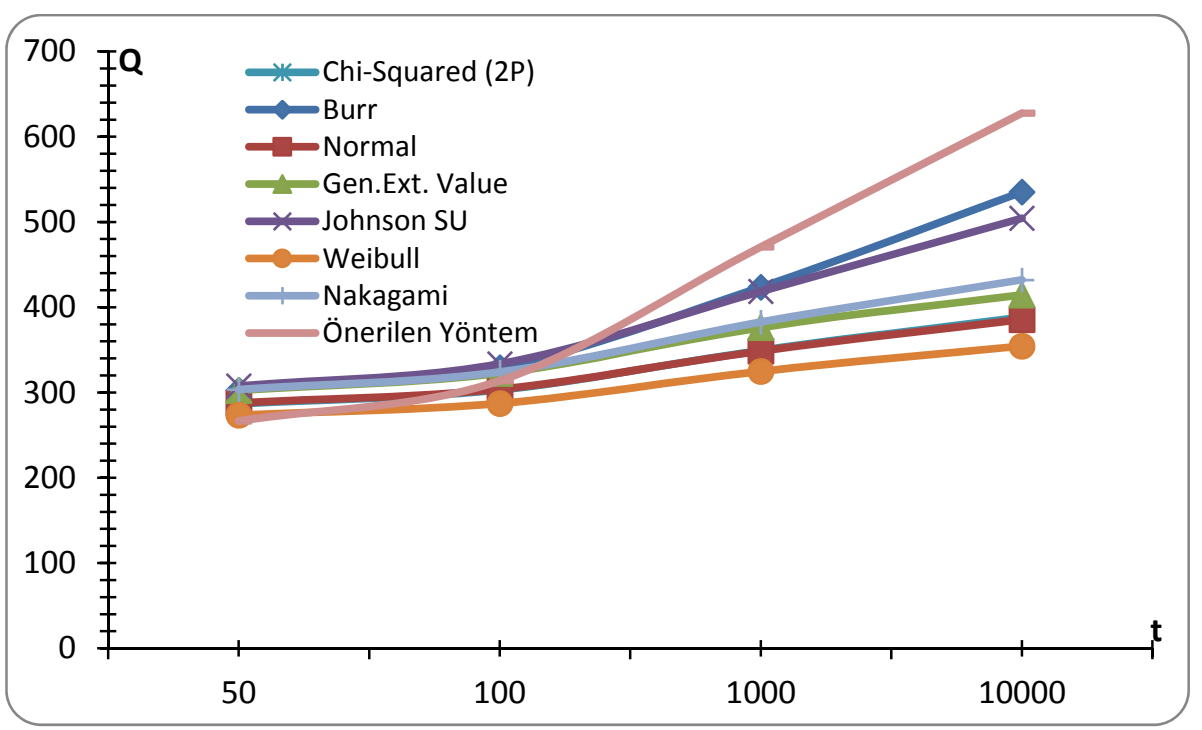

Şekil 13. Fırat 2147 nolu istasyon için Q-T grafiği 


\subsection{Momentlere Dayalı Bölgesel Taşkın Frekans Analizi Sonuçları}

Çalışmada Fırat havzası üzerinde seçilmiş olan 6 adet istasyona ait veriler kullanılarak bu istasyonlara ait ortalama debi (Q ort), L moment oranları ve uyumsuzluk ölçüsü $\mathrm{D}_{\mathrm{i}}$ hesaplanmıştır. Hesaplanan değerler tablo 15 'de verilmişstir.

Tablo 15. Fırat Havzasındaki istasyonlara ait L-moment oranları ve Uyumsuzluk Ölçüsü Değerleri

\begin{tabular}{|c|c|c|c|c|c|c|}
\hline $\begin{array}{l}\text { İstasyon } \\
\text { No }\end{array}$ & $\begin{array}{l}\text { N gözlem } \\
\text { süresi (yıl) }\end{array}$ & Qort & $\mathbf{t}_{2}$ & $\mathbf{t}_{3}$ & $\mathbf{t}_{4}$ & $\mathbf{D}_{\mathrm{i}}$ \\
\hline 2141 & 21 & 258.33 & 0.2157 & 0.1787 & 0.1783 & 1.43 \\
\hline 2119 & 26 & 459.08 & 0.1958 & 0.0937 & 0.0844 & 1.62 \\
\hline 2122 & 31 & 543.52 & 0.2233 & 0.0846 & 0.1110 & 0.07 \\
\hline 2124 & 37 & 46.48 & 0.2643 & 0.1187 & 0.0874 & 1.43 \\
\hline 2133 & 30 & 524.30 & 0.2010 & 0.0174 & 0.1189 & 1.07 \\
\hline 2147 & 34 & 167.18 & 0.1973 & 0.0797 & 0.1457 & 0.37 \\
\hline \multicolumn{3}{|c|}{ Ağırlıklı Bölgesel Ortalama } & 0.2182 & 0.0918 & 0.1181 & \\
\hline
\end{tabular}

Hesaplanan uyumsuzluk ölçüsü değerleri incelendiğinde kritik $\mathrm{D}_{\mathrm{i}}$ değeri olan 1.648 değerinden küçük çıktığından dolayı seçilen tüm istasyonların birbirleri ile uyumlu olduğu tespit edilmiştir.

Bölgeye ait heterojenlik ölçüsü değerleri X test programı yardımı ile hesap edilmiştir. Hesaplanan değerler tablo 16 'da verilmiştir.

Tablo 16. Fırat Havzası için hesaplanan Heterojenlik Ölçüsü Değerleri

\begin{tabular}{|l|l|}
\hline Gözlenen değerlerin grup L-Cv lerin standart sapması & 0.0255 \\
\hline Grup L-Cvlerinin standart sapmasının simülasyon ortalamaları & 0.0244 \\
\hline Grup L-Cvlerinin standart sapmasının simülasyonlarının standart sapması & 0.0081 \\
\hline Standart test değeri H(1) & 0.14 \\
\hline Gözlenmiş ortalamaların L-Cv/L-skew mesafesi & 0.0434 \\
\hline Ortalama L-Cv/ L-skew mesafesinin simülasyon ortalaması & 0.0658 \\
\hline Ortalama L-Cv/L-skew(Cs) mesafesinin simülasyon standart sapması & 0.0185 \\
\hline Standart test değeri H(2) & -1.21 \\
\hline Gözlenmiş ortalamanın L-CV/L-kurt(Ck) mesafesi & 0.0457 \\
\hline Ortalama L-Cv/ L-kurt mesafesinin simülasyon ortalaması & 0.0821 \\
\hline Ortalama L-Cv/L-kurt mesafesinin simülasyon standart sapması & 0.0199 \\
\hline Standart test değeri H(3) & -1.83 \\
\hline
\end{tabular}


Hesaplanan $\mathrm{H}_{1}$ değerleri incelendiğinde hesaplanan değerlerin 1 değerinden küçük olduğu ve bölgenin homojen olduğu söylenebilir. $\mathrm{H}_{2}$ ve $\mathrm{H}_{3}$ değerleri 2 değerinden küçük olduğundan bölge muhtemelen heterojen sonucu çıkmaktadır. Hosking ve Wallis (1993), $\mathrm{H}_{1}$ 'in homojen ve heterojen bölgelerin ayrımında daha güçlü olduğunu öne sürmüşlerdir[10].Bu nedenle bölge homojen kabul edilerek hesaplamalara devam edilmiştir. Ayrıca seçilen istasyonlar için uyumun iyiliği testi sonucu beş adet olasılık dağılım fonksiyonu için L-basıklık ve Z değerleri hesaplanmıştır. Hesaplanan değerler tablo 17 'de verilmiştir.

Tablo 17. Uyumun iyiliği test sonuçları

\begin{tabular}{|l|l|l|}
\hline $\begin{array}{l}\text { Olasılık Dağılım } \\
\text { Fonksiyonu }\end{array}$ & L-Basıklık & $\mathbf{Z}$ değeri \\
\hline Gen. Logistic & 0.174 & 2.30 \\
\hline Gen. Extreme Value & 0.124 & $0.29^{*}$ \\
\hline Log. Normal & 0.129 & $0.50^{*}$ \\
\hline PearsonType III & 0.125 & $0.32^{*}$ \\
\hline Gen. Pareto & 0.026 & -3.70 \\
\hline
\end{tabular}

Hesaplanan $\mathrm{Z}$ değerlerine bakılarak 1.68 değerine eşit veya küçük hesaplanan olasılık dağılım fonksiyonları en uygun dağılım olarak belirlenmiştir. Hesaplanan $Z$ değerlerine göre Gen. Extreme Value, Log. Normal ve Pearson Type III dağılımları \% 90 anlamlılık seviyesinde en uygun dağılım olarak belirlenmiştir.

Belirlenen dağılımlara ait parametrelerin yanı sıra Wakeby dağılımına ait parametreler L momentler yöntemi ile belirlenmiş ve hesaplanan parametreler tablo 18 'de verilmiştir.

Tablo 18. \%90 seviyesinde kabul edilen dă̆llımlara ait parametrelerin tahmini

\begin{tabular}{|l|c|c|c|c|c|}
\hline \multirow{2}{*}{ O.Y.F. } & \multicolumn{5}{|c|}{ Parametreler } \\
\cline { 2 - 6 } & $\boldsymbol{\xi}$ & $\boldsymbol{\alpha}$ & $\boldsymbol{k}$ & & \\
\hline Gen. Ext. Val. & 0.837 & 0.349 & 0.125 & & \\
\hline Log. Normal & 0.964 & 0.381 & -0.188 & & \\
\hline \multirow{2}{*}{ Pears. Type III } & $\boldsymbol{\mu}$ & $\boldsymbol{\sigma}$ & $\boldsymbol{\gamma}$ & & \\
\cline { 2 - 7 } & 1.000 & 0.391 & 0.562 & & $\boldsymbol{\Delta}$ \\
\hline \multirow{2}{*}{ Wakeby } & $\boldsymbol{\xi}$ & $\boldsymbol{\alpha}$ & $\boldsymbol{\beta}$ & $\boldsymbol{\gamma}$ & -0.136 \\
\cline { 2 - 7 } & 0.317 & 1.666 & 3.904 & 0.390 & \\
\hline
\end{tabular}

$\xi$ : konum parametresi, $\alpha$ : ölçek parametresi, $k$ : şekil parametresi, $\mu$ : konum parametresi, $\sigma$ : ölçek parametresi, $\gamma$ : şekil parametresi 
Hesaplanan parametreler yardımıyla seçilen dağılımlar kullanılarak 50, 100, 1000 ve 10000 yıl tekerrür aralıkları için taşkın debileri hesap edilmiştir. Her bir istasyon için hesaplanan değerler aşağıda verilmiştir.

Tablo 19. Fırat 21-041 nolu istasyon için hesaplanan bölgesel taşkın debileri

\begin{tabular}{|l|l|l|l|l|}
\hline & \multicolumn{4}{|c|}{ Tekerrür Aralı̆̆ı (Yıl) } \\
\hline & $\mathrm{Q}_{50}$ & $\mathrm{Q}_{100}$ & $\mathrm{Q}_{1000}$ & $\mathrm{Q}_{10.000}$ \\
\hline Gen. Ext. Val. & 494.60 & 531.56 & 633.03 & 708.89 \\
\hline Log. Normal & 495.84 & 536.38 & 661.72 & 779.31 \\
\hline PearsonType III & 494.54 & 533.66 & 651.88 & 758.86 \\
\hline Wakeby & 490.15 & 518.05 & 578.08 & 608.02 \\
\hline Önerilen Yöntem & 465 & 547.40 & 821.1 & 1094.8 \\
\hline
\end{tabular}

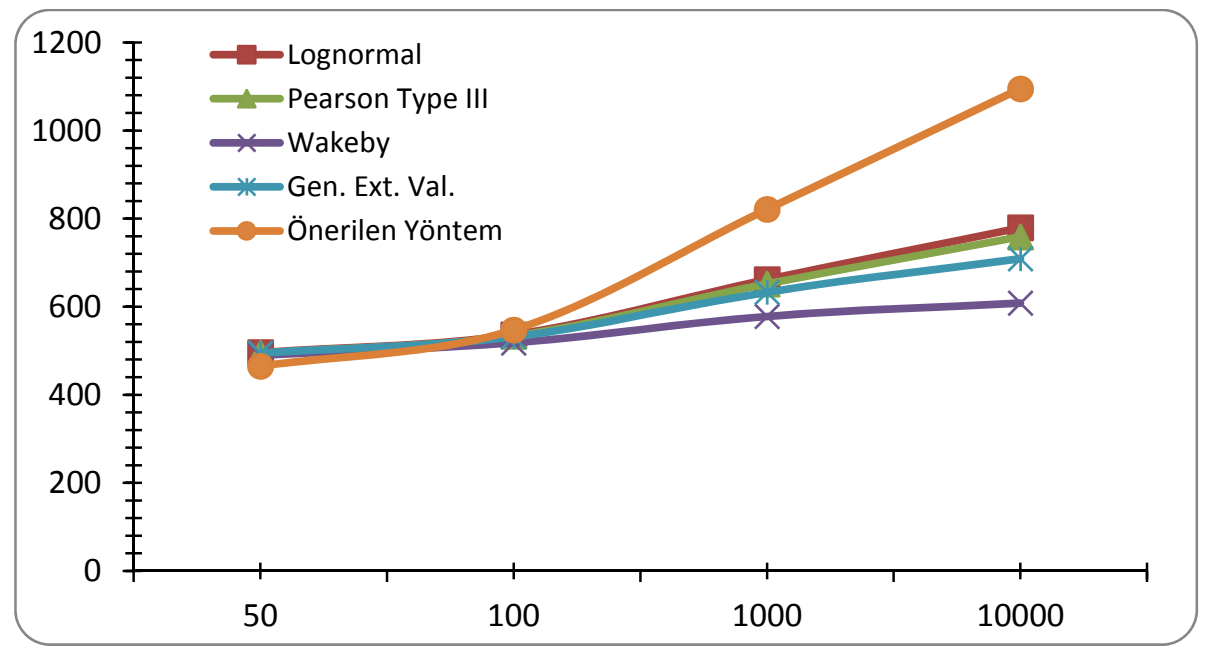

Şekil 14. Firat 21-041 nolu istasyon için Q-t grafiği

Tablo 20. Fırat 2119 nolu istasyon için hesaplanan bölgesel taşkın debileri

\begin{tabular}{|l|l|l|l|l|}
\hline & \multicolumn{4}{|c|}{ Tekerrür Aralı̆̆ı (Yıl) } \\
\hline & $\mathrm{Q}_{50}$ & $\mathrm{Q}_{100}$ & $\mathrm{Q}_{1000}$ & $\mathrm{Q}_{10.000}$ \\
\hline Gen. Ext. Val. & 878.95 & 944.63 & 1124.95 & 1259.76 \\
\hline Log. Normal & 881.15 & 953.20 & 1175.94 & 1384.92 \\
\hline PearsonType III & 878.84 & 948.38 & 1158.45 & 1348.58 \\
\hline Wakeby & 871.01 & 920.62 & 1027.31 & 1080.52 \\
\hline Önerilen Yöntem & 787.30 & 926.80 & 1390.20 & 1853.50 \\
\hline
\end{tabular}




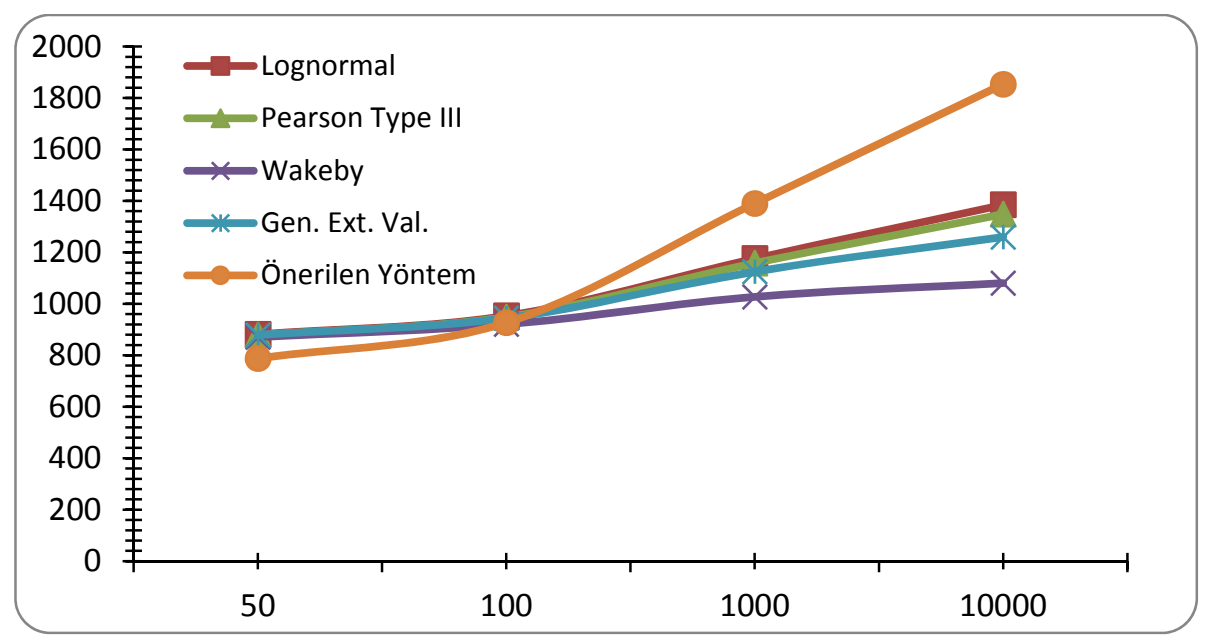

Şekil 15. Fırat 2119 nolu istasyon için Q-t grafiği

Tablo 21. Fırat 2122 nolu istasyon için hesaplanan bölgesel taşkın debileri

\begin{tabular}{|l|l|l|l|l|}
\hline & \multicolumn{4}{|c|}{ Tekerrür Aralı̆̆ı (Yıl) } \\
\hline & $\mathrm{Q}_{50}$ & $\mathrm{Q}_{100}$ & $\mathrm{Q}_{1000}$ & $\mathrm{Q}_{10.000}$ \\
\hline Gen. Ext. Val. & 1040.60 & 1118.36 & 1331.84 & 1491.45 \\
\hline Log. Normal & 1043.21 & 1128.50 & 1392.21 & 1639.62 \\
\hline PearsonType III & 1040.47 & 1122.79 & 1371.50 & 1596.60 \\
\hline Wakeby & 1031.24 & 1089.94 & 1216.24 & 1279.24 \\
\hline Önerilen Yöntem & 829.7 & 976.7 & 1465 & 1953.3 \\
\hline
\end{tabular}

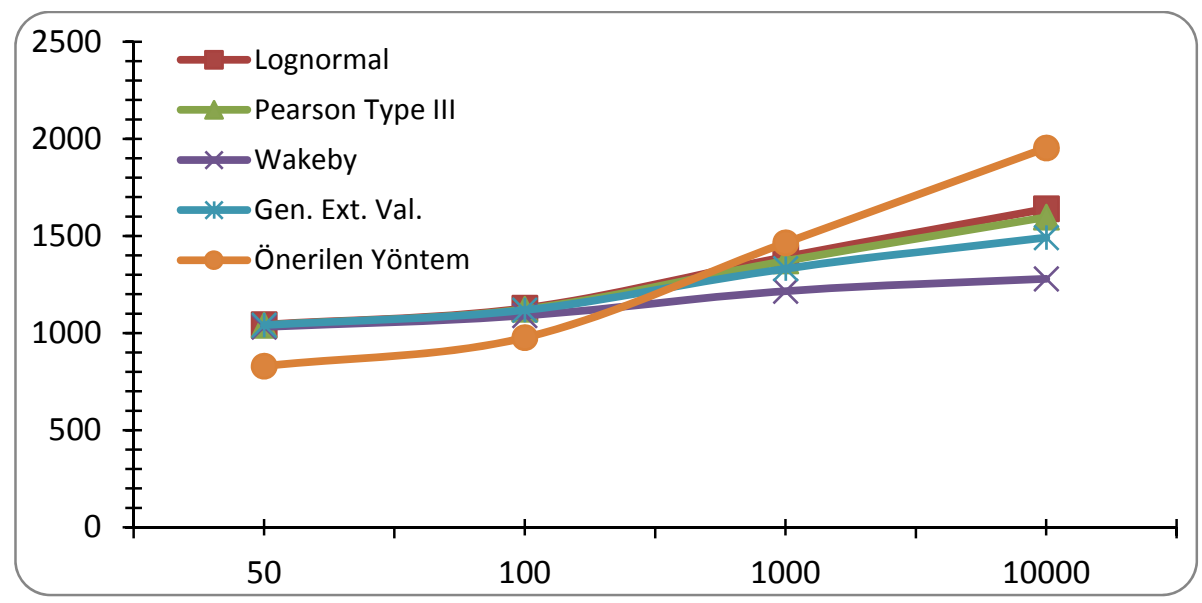

Şekil 16. Firat 2122 nolu istasyon için Q-t grafiği 
Tablo 22. Fırat 2124 nolu istasyon için hesaplanan bölgesel taşkın debileri

\begin{tabular}{|l|l|l|l|l|}
\hline & \multicolumn{4}{|c|}{ Tekerrür Aralı̆̆ı (Yıl) } \\
\hline & $\mathrm{Q}_{50}$ & $\mathrm{Q}_{100}$ & $\mathrm{Q}_{1000}$ & $\mathrm{Q}_{10.000}$ \\
\hline Gen. Ext. Val. & 88.69 & 95.64 & 113.90 & 127.55 \\
\hline Log. Normal & 89.21 & 96.51 & 119.06 & 140.22 \\
\hline PearsonType III & 88.98 & 96.02 & 117.29 & 136.54 \\
\hline Wakeby & 88.19 & 93.21 & 104.01 & 109.40 \\
\hline Önerilen Yöntem & 81.1 & 95.5 & 143.2 & 190.9 \\
\hline
\end{tabular}

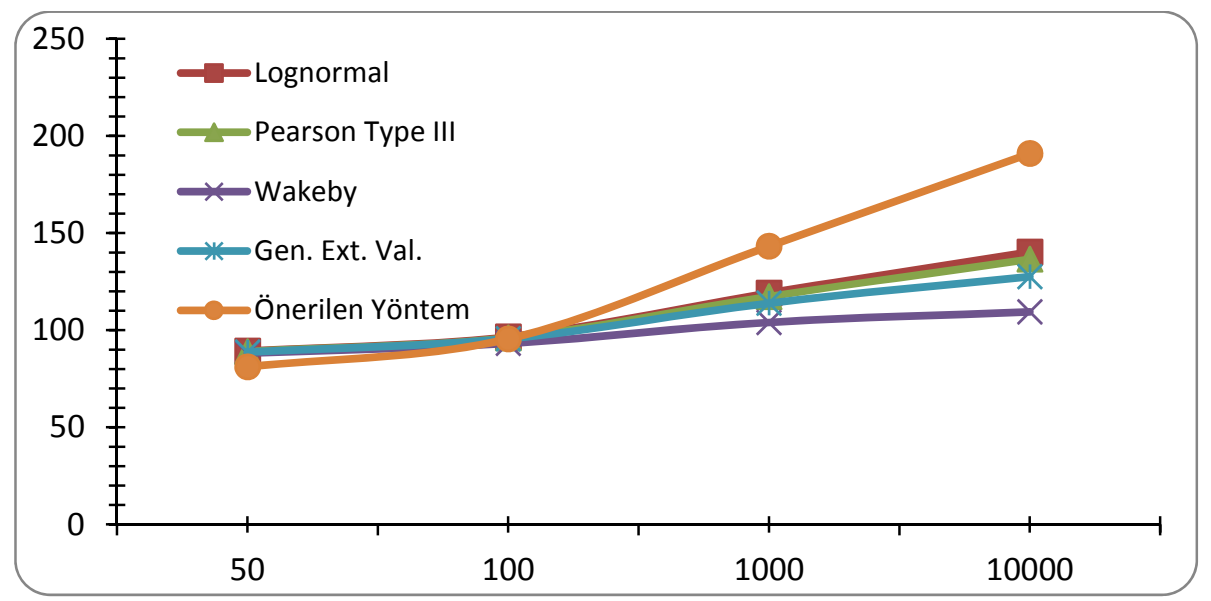

Şekil 17. Fırat 2124 nolu istasyon için Q-t grafiği

Tablo 23. Fırat 2133 nolu istasyon için hesaplanan bölgesel taşkın debileri

\begin{tabular}{|l|l|l|l|l|}
\hline & \multicolumn{4}{|c|}{ Tekerrür Aralı̆̆ı (Yıl) } \\
\hline & $\mathrm{Q}_{50}$ & $\mathrm{Q}_{100}$ & $\mathrm{Q}_{1000}$ & $\mathrm{Q}_{10.000}$ \\
\hline Gen. Ext. Val. & 1003.81 & 1078.82 & 1284.75 & 1438.72 \\
\hline Log. Normal & 1006.32 & 1088.60 & 1342.99 & 1581.65 \\
\hline PearsonType III & 1003.68 & 1083.10 & 1323.01 & 1540.15 \\
\hline Wakeby & 994.78 & 1051.40 & 1173.24 & 1234.01 \\
\hline Önerilen Yöntem & 943.4 & 1110.5 & 1665.8 & 2221 \\
\hline
\end{tabular}




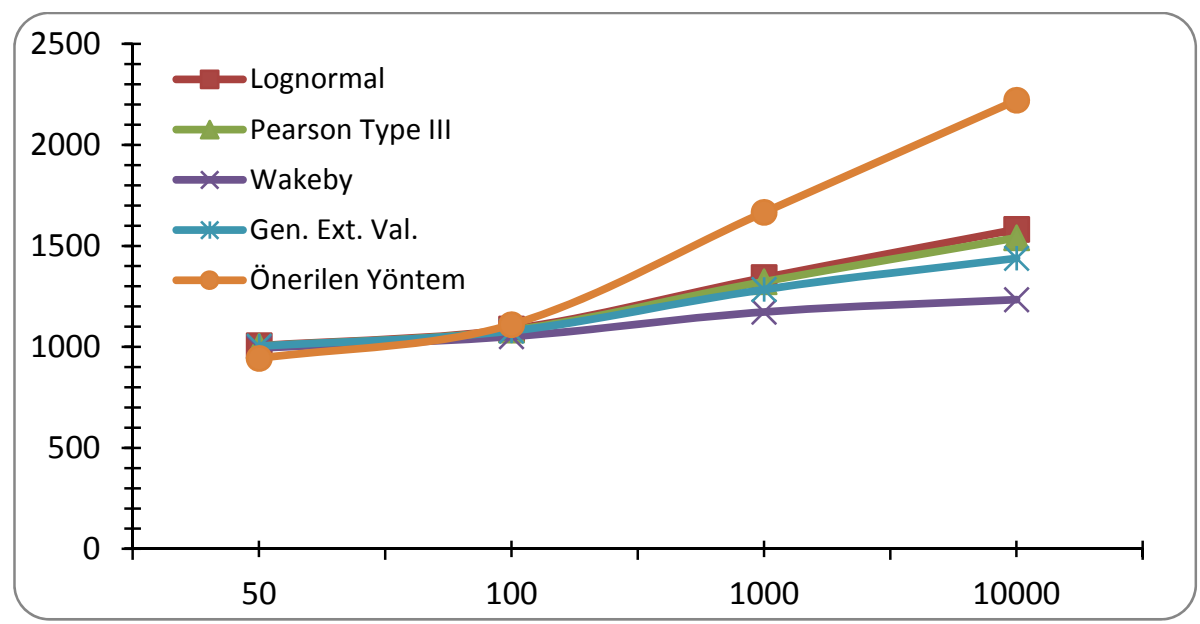

Şekil 18. Fırat 2133 nolu istasyon için Q-t grafiği

Tablo 24. Fırat 2147 nolu istasyon için hesaplanan bölgesel taşkın debileri

\begin{tabular}{|l|l|l|l|l|}
\hline & \multicolumn{4}{|c|}{ Tekerrür Aralı̆̆ı (Yıl) } \\
\hline & $\mathrm{Q}_{50}$ & $\mathrm{Q}_{100}$ & $\mathrm{Q}_{1000}$ & $\mathrm{Q}_{10.000}$ \\
\hline Gen. Ext. Val. & 320.07 & 343.99 & 409.65 & 458.74 \\
\hline Log. Normal & 320.87 & 347.11 & 428.22 & 504.32 \\
\hline PearsonType III & 320.03 & 345.35 & 421.85 & 491.09 \\
\hline Wakeby & 317.19 & 335.25 & 374.10 & 393.47 \\
\hline Önerilen Yöntem & 266.7 & 313.8 & 470.7 & 627.6 \\
\hline
\end{tabular}

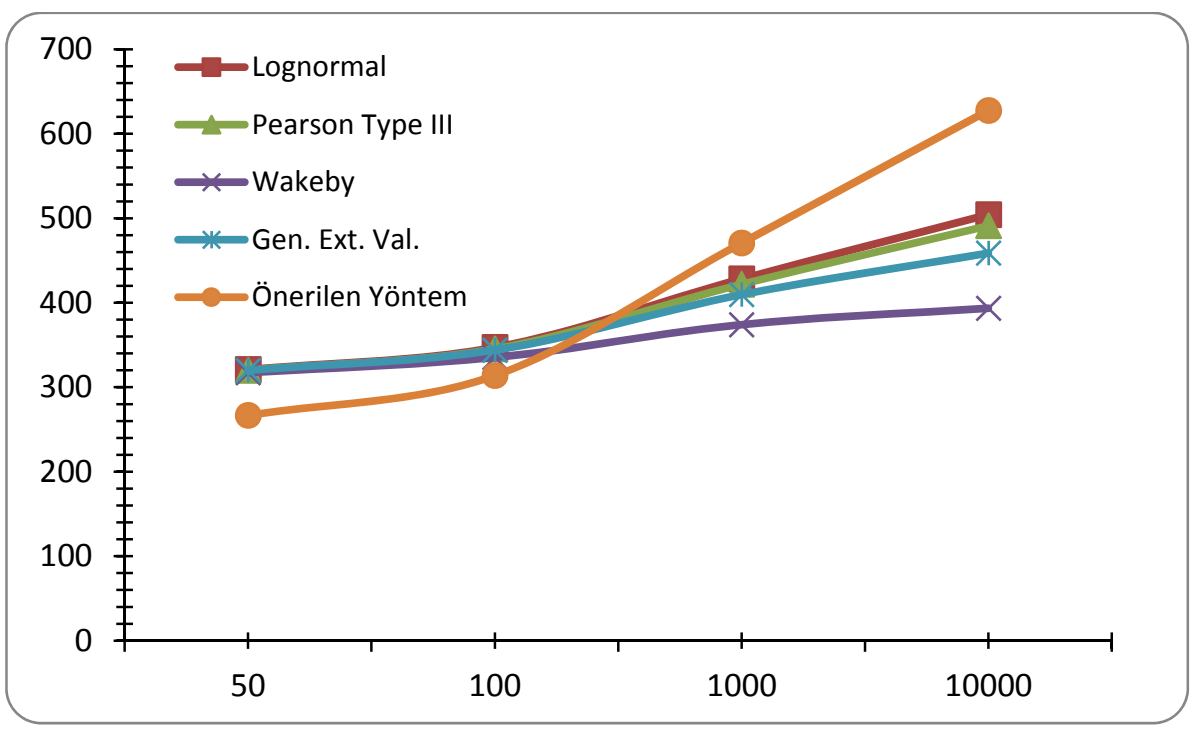

Şekil 19. Firat 2147 nolu istasyon için Q-t grafiği 


\section{SONUÇLAR}

$\mathrm{Bu}$ çalışmada Fırat havzası üzerinde bulunan 6 adet gözlem istasyonuna ait veriler kullanılmıştır. Bu veriler içerisindeki aykırı değerler hem Dixon Thompson hem de çalışmada önerilen yöntem kullanılarak tespit edilmiştir. Aykırı değerlerin etkisi olmaksızın 50, 100, 1000 ve 10000 yılda gelecek maksimum taşkın Kolmogorov Smirnov, Anderson Darling ve Ki Kare uyumun iyiliği testleri sayesinde kullanmış olduğumuz veri setlerine en uygun olan olasılık dağılım fonksiyonları belirlenmiş ve taşkın debileri bu olasılık yoğunluk fonksiyonları kullanılarak, L momentlere dayalı bölgesel olarak belirlenen OYF parametreleri kullanılarakve önerilen yöntemle çizilen $\alpha$-T diyagramlarının doğal eğimine uyacak şekilde ayrı ayrı hesap edilmiştir.. Hesap edilen değerler incelendiğinde özellikle aykırı değerler belirlenip veri setlerinde çıkarıldıktan sonra hesap edilen taşkın debileri L momentler yönteminde oldukça düşük hesap edilmiştir. L momentler yöntemi ile hesap edilen 50 yıl ve 10000 yılda bir gelebilecek olan taşkın debileri arasındaki farkın çok az olduğu ve bu hesaplanan sonuçların su yapılarının tasarım debisi olarak kullanılmasının sakıncalı olabileceği düşünülmektedir. Noktasal olarak belirlenen taşkın debileri incelendiğinde ise 50 ve 100 yıl gibi kısa dönemlerde gelebilecek debilerin önermiş olduğumuz yönteme kıyasla daha yüksek hesaplandığ 1 , buna karşın daha uzun dönemler 1000 ve 10000 yıl göz önüne alındığında hesaplanan taşkın debilerinin önermiş olduğumuz yönteme göre bazı istasyonlarda daha küçük hesaplanırken bazı istasyonlarda ise yakın sonuçlarda hesaplandığı görülmüştür.

Bütün bu sonuçlar incelendiğinde L momentler yöntemi ile yapılan hesaplamalarda aykırı değerlerin veri seti içerisinden çıkartılması debi tekerrür eğrisinin yatıklaşmasına ve sonuçların oldukça düşük çıkmasına neden olduğu bu nedenle L momentler yönteminin sağlıklı sonuçlar vermediği düşünülmektedir. Noktasal olarak belirlenen OYF kullanılarak yapılan hesaplamalarda ise kısa tekerrür aralığında gelebilecek olan taşkın debilerinin nispeten daha yüksek hesaplandığı, bunun yanında daha uzun tekerrür süreleri için hesaplanan taşkın debi değerlerinin L momentler yöntemi ile hesaplanan değerlerle kıyaslandığında daha makul değerlerde hesaplandığı düşünülmüştür ve hesaplanan bu debi değerleri önerilmiş olan yöntemle kıyaslandığında daha yakın sonuçlar verdiği görülmüştür.

Sonuç olarak aykırı değerlerin veri setinden çıkarılarak hesaplamaların yapılması durumunda önerilen yöntem ve noktasal taşkın frekans analizi yönteminin L momentler yöntemine göre daha iyi sonuçlar verdiği ve bu iki yöntemin kullanılmasınındaha uygun olduğu düşünülmektedir.

\section{Semboller}

$\alpha \quad$ : Önerilen yöntem test istatistiği değeri

$\mu \quad$ : Ortalama parametresi

$\sigma \quad$ : Standart sapma parametresi

m : Üst limit

n : Örnekteki eleman sayısı

R : Dixon- Thompson test istatistiği değeri 
$\bar{X} \quad$ : Örnek ortalama değeri

Z : Standart normal uç değer

$\beta \quad$ : Olasılık ağırlıklı moment

Cv : Varyasyon katsayısı

\section{Kaynaklar}

[1] Wu, L.,Mixed Effects Models for Complex Data, Chapman and Hall / CRC, 2009.

[2] Liu, H., Shah, S., Jiang, W., On-line Outlier Detection and Data Cleaning, Computers \& Chemical Engineering, 28, 9, 1635-1647, 2004.

[3] Mc Cuen, R. H., Modeling Hidrologic Change: Statistical Methods, Lewis Publishers, 2003.

[4] Stagge, J. H., Field Evaluation of Hydrologic and Water Quality Benefits of Grass Swales for Managing Highway Runoff, Master of Science, Faculty of the Graduate School of the University of Maryland, College Park, 2006.

[5] Gibbons, R. D.,Bhaumik, D., Aryal, S.,Statistica lMethods for Ground water Monitoring, Second Edition, John Wiley and Sons, Inc., 2009.

[7] Cunnane, C., Review of Statistical Methods for Flood Frequency Estimation, in Hydrologic Frequency Modeling, 49-95, 1987.

[8] Seçkin, N., Ceyhan ve Seyhan Havzalarının Bölgesel Taşkın Frekans Analizi, Yüksek Lisans Tezi, Çukurova Üniversitesi Fen Bilimleri Enstitüsü, 2002.

[9] Mkhandi, S. H.,Kachroo, R. K.,Flood Frequency Analysis of Southern Africa: II. Identification of Regional Distributions, Hydrological Sciences, 45, 449-464, 2000.

[10] Seçkin, N.,L Momentlere Dayalı Gösterge-Sel Metodu ile Bölgesel Taşkın Frekans Analizi,Doktora Tezi, Çukurova Üniversitesi Fen Bilimleri Enstitüsü, 2009.

[11] Şorman, A.Ü., Bölgesel Frekans Analizindeki Son Gelişmeler ve Batı Karadeniz’de Bir Uygulama, İMO Teknik Dergi, 3155-3169, 2004.

[12] Vogel, R.M.,Fennessey, N.M., L Moment DiagramsShouldReplace Product Moment Diagrams, WaterResourcesResearch, 29, 6, 1745-1752, 1993.

[13] Hosking, J.R.M., Wallis J.R., RegionalFrequency Analysis An ApproachBased on LMoments, Cambridge UniversityPress, 1997. 
